\title{
PREFACE TO THE SPECIAL ISSUE ON MUMMY STUDIES
}

\author{
In memoriam \\ Arthur Carl Aufderheide
}

(1922-2013)

Aimed at marking the creation of the "Lithuanian Mummy Project" - an investigation of mummified remains present in the most southern of the Baltic States we wished to gather research articles carried out by our collaborators and colleagues active in the field of mummy studies. This XXIII volume of Papers on Anthropology contains a selection of invited papers by mummy scholars from America, Asia, Australia, and Europe. In accordance with the multidisciplinary nature of modern mummy studies, the following essays encompass a wide range of subjects, including palaeopathology, taphonomy, history, cultural anthropology, and analytical methods applied to ancient bodies, either human or animal. Authoritative researchers with passion and experience in the field, report in detail on cases from Lithuania, Germany, Greece, Egypt, and Korea, as just a few examples of the widely-dispersed presence of preserved remains around the globe, and emphasise the importance of the cultural and scientific heritage that mummies represent. We hope this volume will act as a catalyst to many other intriguing mummy studies projects.

Dr Dario Piombino-Mascali

Prof. Rimantas Jankauskas

Department of Anatomy, Histology and Anthropology

Faculty of Medicine

Vilnius University 